http://dx.doi.org/10.18778/7969-455-6.06

Sylwia Syndoman

Warszawa

\title{
POLSKO-AUSTRIACKIE STOSUNKI DYPLOMATYCZNE I KONTAKTY POLITYCZNE W LATACH 1970-1989
}

\section{Zarys historyczny kontaktów polsko-austriackich}

Stosunki polsko-austriackie we współczesnej historii są bardzo interesującym i ciekawym tematem dla współczesnego badacza. W polskiej historiografii wiele miejsca zostało poświęconego niemieckiej i sowieckiej problematyce, natomiast zagadnienia związane z problematyką austriacką wymagają jeszcze wielu publikacji i opracowań, ponieważ brak jest $\mathrm{w}$ tej dziedzinie fachowej literatury. Również zagłębiając się w analizę austriackich badań historycznych, dochodzimy do wniosków, że skupiły one swoją uwagę na stosunkach z krajami Europy Zachodniej, natomiast kwestie relacji z państwami bloku sowieckiego stanowią bardzo znikomy procent publikacji i materiałów źródłowych. Od czasów zimnej wojny do przełomu lat 1989-1990 Austria i Polska znalazły się po przeciwnej stronie, tzw. żelaznej kurtyny. Każde z tych państw mimo specyficznych uwarunkowań, przed jakimi postawiła ich historia, próbowało na swój sposób wprowadzić w większym lub w mniejszym stopniu samodzielną politykę zagraniczna, gospodarczą czy też kulturalną.

Polska jako państwo satelickie i zależne od naszego wschodniego sąsiada nie miała możliwości prowadzenia samodzielnej polityki na arenie międzynarodowej. Było to uwarunkowane również stosunkiem wasalnym, tzw. elity do towarzyszy radzieckich. Pewien wyłom w latach słusznej i niezachwianej ideologii okresu komunizmu w Polsce, zdaniem niektórych historyków, próbowali zrobić Władysław Gomułka w roku 1956 w okresie VIII plenum KC (słynny marsz kolumn wojsk radzieckich na Warszawę i rozmowy Gomułki z władzami Chińskiej Republiki Ludowej) oraz Edward Gierek swą otwartą polityką gospodarczą na kraje zachodnie - lata siedemdziesiąte. 
Stosunki między Polską a Austrią w latach 70 i 80 miały inny wymiar niż w ramach państwowości Habsburgów. Były to przede wszystkim stosunki dwóch państw suwerennych.

W interesie zarówno Polski, jak i Austrii leżała obrona wersalskiego ładu pokojowego, bo wraz z jego upadkiem groziła katastrofalnymi następstwami zmiana uwarunkowań międzynarodowych. Rozwój społeczno-gospodarczy Austrii, jaki miał miejsce po uregulowaniu tak zwanego problemu austriackiego, stawiał ją w rzędzie państw szybko rozwijających się, stwarzając dogodne warunki do pokojowej współpracy, zacieśniania polsko-austriackich kontaktów politycznych, dyplomatycznych, kulturalnych, naukowych i wzajemnie korzystnej współpracy gospodarczo-handlowej.

\subsection{Stosunki dyplomatyczne między Polską, a Austrią}

Chcąc rozprawiać na temat stosunków dyplomatycznych między Polską a Austrią należy zapoznać się z ogólnie przyjmowaną definicją stosunków dyplomatycznych, która mówi, że jest to oficjalna forma najwyższych stosunków międzypaństwowych, które stanowią realizację prawa legacji każdego państwa i służą wykonywaniu jego polityki zagranicznej. Ich nawiązanie może nastąpić $\mathrm{w}$ drodze porozumienia obu zainteresowanych stron ${ }^{1}$.

Po II wojnie światowej Europę opanował nowy ład dzielący ją na dwa przeciwstawne obozy. Republika Austrii była pod wpływem Sojuszniczej Komisji Kontroli ds. Austrii, aż do 15 maja 1955 roku, kiedy to Austria uzyskała status państwa neutralnego ${ }^{2}$. Polska z kolei w kwestiach dyplomatycznych była zależna od ZSRR. Po uznaniu wieczystej neutralności Austrii przez Polskę, oba państwa przystąpiły do podpisania pierwszej dwustronnej umowy państwowej w 1956 roku³ .

Przełomowym momentem w stosunkach dyplomatycznych między Polską a Austrią była wizyta ówczesnego ministra spraw zagranicznych Austrii Bruno Kreisky'ego oraz sekretarza stanu w MSZ Franza Geschnitzera w Polsce. Delegacja została zaproszona do Polski przez ministra spraw zagranicznych Adama Rapackiego w dniach 1-3 marca 1960 roku4. W do-

1 http://portalwiedzy.onet.pl/85285,,,, stosunki_dyplomatyczne,haslo.html [11.05.2012].

2 A. Kisztelińska-Węgrzyńska, Traktaty polsko-austriackie z lat 1955-1989. Wybór umów dwustronnych, s. 12.

${ }_{3}$ Umowa między PRL i Austriackim Rządem Federalnym w sprawie komunikacji lotniczej z 8.02.1956 roku, w: A. Kisztelińska-Węgrzyńska, Traktaty polsko-austriackie..., s. 31.

4 Z. Tomkowski, Powstanie Towarzystwa Polsko-Austriackiego, w: Z. Tomkowski (red.) 
brze układających się stosunkach polsko-austriackich pojawiły się dążenia do wzajemnego rozwoju społecznego. Konsekwencją tego było spotkanie organizacyjne przedstawicieli środowisk naukowych uczelni warszawskich, instytucji państwowych, organizacji społecznych i młodzieżowych, które odbyło się z inicjatywy prof. Stanisława Turskiego ${ }^{5}$. Uczestnicy spotkania poparli inicjatywę profesora i z dniem 28.12.1959 roku postanowili powołać Komitet Organizacyjny Towarzystwa Polsko-Austriackiego.

Intensyfikacja stosunków dyplomatycznych między Polską, a Austrią nastąpiła z początkiem lat 70. XX wieku. W styczniu 1971 roku oficjalną wizytę w Polsce złożył minister spraw zagranicznych Republiki Austrii Rudolf Kirchschlaeger. Przyjęty został przez Józefa Cyrankiewicza i Piotra Jaroszewicza ${ }^{6}$. Zawarto wielostronną umowę handlową między Polską, a Austrią której głównym założeniem było całkowite unieważnienie wszelkich istniejących ograniczeń ilościowych wymiany towarowej, a także wprowadzono wielostronność wzajemnych rozliczeń z tytułu obrotu towarowego ${ }^{7}$. Głównym wydarzeniem w stosunkach dyplomatycznych w roku 1972 była wizyta ministra spraw zagranicznych Kazimierza Olszewskiego w Wiedniu i podpisanie umowy o wzajemnych stosunkach kulturalno-naukowych. Jego istotą była wymiana między specjalistami naukowymi, a także wspólne badania naukowe ${ }^{8}$.

W tym samym roku, we wrześniu, minister handlu zagranicznego Kazimierz Olszewski i minister handlu i przemysłu Austrii Josef Staribacher podpisali umowę w sprawie obrotu torowego i płatniczego oraz współpracy gospodarczej między obu państwami. Umowa ta była ewenementem we wzajemnych relacjach między państwami o odmiennych systemach gospodarczych? .

Również polskie delegacje odnosiły sukcesy dyplomatyczne, kiedy to w marcu 1972 roku, w Wiedniu ówczesny wiceminister spraw zagranicznych Stanisław Trepczyński podpisał umowę między PRL, a Międzynarodową Agencją Energii Atomowej. W tym samym roku w Austrii przebywał z oficjalną wizytą Stefan Olszowski minister spraw zagranicznych.

Z zagadnień wspótpracy polsko-austriackiej, s. 11; A. Donath, Działalność Towarzystwa Polsko-Astriackiego, a stosunki polsko-austriackie, w: (red) W. Kucharski, Z. Tomkowski, Wspótpraca Polsko-Austriacka. Materiały polsko-austriackiego sympozjum naukowego zorganizowanego w Lublinie 8 czerwca 1976 r. z okazji 30. rocznicy powstania Towarzystwa Austriacko-Polskiego, s. 144.

5 Z. Tomkowski, Powstanie Towarzystwa Polsko-Austriackiego..., s. 12.

${ }^{6}$ MSZ, Stosunki dyplomatyczne Polski 1944-1981 r. Informator. Tom II, cz. I, s. 15.

7 K. Olszewski, Austria ważny partner gospodarczy Polski, w: Austria-Polska. Czasopismo Gospodarczo-Kulturalne, nr 2 (83) czerwiec 1972.

8 J. Gajdek, Polen-Österreichische Beziehungen in den 70er, 80er, 90er Jahren in Spiegel der Presse der beiden Länder, Wien 1999, s. 25.

9 Ibidem, s. 16. 
Przyjęty został przez prezydenta Republiki Austrii Franza Jonasa oraz kanclerza Bruno Kreisky'ego. Spotkanie dotyczyło rozwoju stosunków dyplomatycznych między PRL, a Austrią.

W dniach 24-28 września 1972 przebywał w Polsce austriacki minister rolnictwa i leśnictwa inż. Dr O. Weihs. Ministre przeprowadził rozmowy na tematy gospodarcze oraz zwiedził Instytut Technologii Drewna w Poznaniu. Wizyta Weihsa stanowiła rewizytę, ponieważ minister inż. J. Popko gościł w 1971 roku w Austrii ${ }^{10}$. W czerwcu 1973 roku w Polsce z wizytą przebywał kanclerz Austrii Kreisky. Od tego momentu nastąpił rozwój stosunków polsko-austriackich ${ }^{11}$. Podczas jego obecności w Polsce został podpisany 10-letni projekt dotyczący gospodarczej, przemysłowej oraz naukowo-technicznej współpracy. Oba państwa podkreśliły przydatność dalszego pogłębiania politycznej współpracy między państwami ${ }^{12}$.

W grudniu 1973 roku przebywał w Austrii minister przemysłu maszynowego T. Wrzaszczyk, który zwiedził zakłady Steyr-Daimler-Puch Sp. Akc. Oraz Vöest-Alpine w Linzu. Polski minister przeprowadził rozmowy z ministrem Austrii Staribacherem, które to dotyczyły rozszerzenia współpracy $\mathrm{w}$ dziedzinie przemysłu silników i kabli oraz modernizacji huty Stalowa Wola. Niespełna parę dni później Austrię odwiedził wicepremier PRL J. Mitręga minister górnictwa i energetyki. Przeprowadził on rozmowy z kanclerzem Austrii Kreiskym i Staribacherem ${ }^{13}$.

Wraz z kontaktami na szczeblu dyplomatycznym nastąpił wzrost wizyt i współpracy między poszczególnymi resortami. 30 września 1974 przebywał w Austrii Prezes Rady Ministrów Piotr Jaroszewicz. Został przyjęty przez prezydenta Austrii Rudolfa Kirchschlägera. Szef rządu polskiego złożył wizytę przewodniczącemu Parlamentu austriackiego Antonowi Benyi oraz burmistrzowi Wiednia Leopoldowi Gratzowi. Z tej okazji kanclerz Bruno Kreisky wydał przyjęcie w zamku Hofburg. Szefowie rządów prowadzili rozmowy na temat stanu i możliwości rozwoju stosunków austriacko-polskich oraz na temat zagadnień międzynarodowych.

Podkreślano wzmocnienie odprężenia politycznego w dziedzinie militarnej, a także akcentowano znaczenie umowy o nierozprzestrzenianiu broni jądrowej. Obie strony wypowiedziały się za podpisaniem międzynarodowej umowy w sprawie całkowitego zakazu stosowania, produkcji i przechowywania broni chemicznej ${ }^{14}$.

\footnotetext{
10 Austria-Polska. Czasopismo Gospodarczo-Kulturalne, nr 2 (87) czerwiec 1973, s. 63.

11 Archiwum MSZ, Stosunki polsko-austriackie, sygn. Z43/84, W.5, t. A. 220, s. 17.

12 J. Gajdek, Polen-Österreichische Beziehungen..., s. 26.

13 Austria-Polska. Czasopismo Gospodarczo-Kulturalne, nr 1 (90) czerwiec 1974, s. 57.

14 Owocna wizyta państwowa, w: Austria-Polska. Czasopismo Gospodarczo-Kultralne,
} nr 1 (94) czerwiec 1975, s. 11. 
W styczniu 1974 roku na zaproszenie marszałka Sejmu Stanisława Gucwy odwiedził PRL Anton Benya. Prowadzono rozmowy z przewodniczącym Wojwódzkiej Rady Narodowej Józefem Klasą wojewodą krakowskim Witem Drapichem, prezydentem miasta Jerzym Pękalą. Podczas tej wizyty odbyło się spotkanie z Prezesem Rady Ministrów Piotrem Jaroszewiczem. Rozmowy dotyczyły rozwoju kontaktów między Polską i Austrią oraz rozszerzenia współpracy gospodarczej ${ }^{15}$. Pod koniec września 1974 roku w Austrii przebywał Prezes Rady Ministrów Piotr Jaroszewicz, przyjął go kanclerz Bruno Kreisky. Podczas tej wizyty podpisano m.in. wspólną deklarację obu rządów o zniesieniu ograniczeń dla polskiego eksportu do Austrii ${ }^{16}$. 11 września 1975 roku podpisana została w Styrii największa w dziejach polsko-austriackich stosunków gospodarczych umowa o kooperacji. Umowa została podpisana w obecności premiera Jaroszewicza i kanclerza Kreiskyego. Umowa ta zapewniała przez 15 lat współpracę w dziedzinie produkcji samochodów ciężarowych ${ }^{17}$.

W maju 1975 roku miało miejsce uhonorowanie stosunków dyplomatycznych między Polska, a Austrią w postaci odznaczenia prezydenta Austrii Rudolfa Kirchschlaegera Wielką Wstęgą Orderu Zasługi PRL ${ }^{18}$. 22 września 1976 roku miała miejsce oficjalna wizyta w Austrii polskiego ministra handlu zagranicznego i gospodarki morskiej prof. J. Olszewskiego. Minister wziął udział w rozmowach gospodarczych zorganizowanych przez Forum Gospodarcze Towarzystwa Austriacko-Polskiego. Minister Olszewski wyraził swoje zadowolenie z podróży, której głównym celem były sprawy Wielkiej Mieszanej Komisji Współpracy Gospodarczej oraz rozmowy z austriackim ministrem handlu zagranicznego Staribacherem ${ }^{19}$.

W 1977 roku Prezes Rady Ministrów Piotr Jaroszewicz wizytował kanclerza Austrii Bruno Kreisky'ego. W rozmowach, które odbyły się podczas tej wizyty dokonano oceny ówczesnego stanu relacji polsko-austriackich. Przedyskutowano też perspektywy dalszego ich rozwoju z uwzględnieniem współpracy gospodarczej i przemysłowej. Jaroszewicz i Kreisky wymienili również poglądy na utrwalenie odprężenia, redukcji zbrojeń i rozbrojenia i stosunków radziecko-amerykańskich ${ }^{20}$.

15 A. Benya, Umocnienie stosunków kulturalnych i gospodarczych, w: Austria-Polska. Czasopismo Gospodarczo-Kulturalne, nr 1 (90) czerwiec 1974, s. 12.

16 MSZ, Stosunki dyplomatyczne Polski 1944-1981r..., s. 21.

17 Austria-Polska. Czasopismo Gospodarczo-Kulturalne, nr 1(98) czerwiec 1976, s. 56.

18 Ibidem, s. 23.

19 Rozmowy gospodarcze z ministrem handlu zagranicznego i gospodarki morskiej Jerzym Olszewskim, w: Austria-Polska, Czasopismo Gospodarczo-Kulturalne, s. 16.

20 Archiwum MSZ, Szyfrogram nr 3752/II, sygn. Z2/83, W. III, t. Austria 1977, A.O. 220, s. 1 . 
W maju 1977 roku przebywał z oficjalną wizytą w Austrii minister J. Kuberski. Zapoznał się z systemem szkolnictwa w austriackich szkołach podstawowych, zawodowych oraz ogólnokształcących. W wyniku rozmów podpisany został protokół przewidujący zorganizowanie w 1978 roku w Austrii wspólnego seminarium pedagogów polskich i austriackich zajmujących się problematyką reformy szkolnej ${ }^{21}$.

Depeszą nr 51 towarzysz Karski podaje, że w rozmowie z prezydentem parlamentu Austrii A. Benya ustalono, że dzięki intensywnemu dialogowi szefów rządów nastąpił, szczególnie w latach 70., dynamiczny rozwój stosunków we wszystkich dziedzinach ${ }^{22}$.

W 1978 roku miało miejsce spotkanie w Wiedniu Podsekretarza Stanu w Ministerstwie Administracji, Gospodarki Terenowej i Ochrony Środowiska Ludwika Ochockiego z Przedstawicielem Ministerstwa Zdrowia i Ochrony Środowiska Austrii E. Bobeckiem. W trakcie spotkania omówiono kwestię podpisania umowy o współpracy $\mathrm{w}$ dziedzinie ochrony środowiska ${ }^{23}$.

W lutym 1978 roku na zaproszenie Związkowego Ministra Sprawiedliwości Republiki Austrii Christiana Brody gościł Minister Sprawiedliwości PRL Jerzy Bafia. Rozmowy Ministra PRL z kanclerzem Kreiskym oraz prezydentem Austrii Kirchschlägerem dotyczyły problematyki prawniczej, kwestii współpracy polsko-austriackiej oraz sytuacji międzynarodowej. Następnie delegacja polska wzięła udział w sympozjum prawników zorganizowanym przez Austriackie Stowarzyszenie Sędziów. Ważnym elementem wizyty było podpisanie umowy o pomocy prawnej w sprawach karnych oraz umowy o ekstradycji między PRL i Republiką Austrii ${ }^{24}$.

W dniach 12-16 czerwca 1978 roku miała miejsce wizyta w Austrii Delegacji Ministerstwa Energetyki i Energii Atomowej na zaproszenie Ministra Austrii Staribachera.

Przewodniczący delegacji odbył rozmowy z prezydentem Austrii Kirchschlägerem.

Celem wizyty było rozszerzenie współpracy i wymiany handlowej w zakresie energii elektrycznej, zapoznanie się z technicznymi i eksploatacyjnymi doświadczeniami w zakresie elektrowni wodnych oraz zbadanie możliwości kooperacyjnych w rozwoju maszyn i urządzeń górniczych ${ }^{25}$.

${ }^{21}$ Archiwum MSZ, Wizyty w Austrii min. Kuberskiego, sygn. Z 42/1, W. III, t. Austria 1977.

22 Archiwum MSZ, Stosunki polityczne PRL-Austria, t. 2/83, III 1977.

23 Archiwum MSZ, Dot. Umowy o ochronie środowiska, sygn. Z 1/84, W. III, 1978.

24 Archiwum MSZ, Wizyta w Wiedniu min. Bafii, sygn. Z1/84, W. III, 1978.

25 Archiwum MSZ, Wyjazdy różne, sygn. Z 1/84, W. III, 1978. 
W dniach 9-12 maja 1978 roku przebywał w Polsce z wizytą Wicekanclerz Austrii Hannes Androsch na zaproszenie Piotra Jaroszewicza. W czasie wizyty wicekanclerz Austrii podkreślił wolę kontynuowania aktywnej polityki neutralnej, zmierzającej do odprężenia politycznego i militarnego. Wicekanclerz Austrii pozytywnie ocenił stosunki między obu krajami. Strona polska przedstawiła wicekanclerzowi Polski, trudności na jakie natrafia eksport polski do Austriii ${ }^{26}$.

Schyłek lat 70 zaowocował jedną ważną delegacją którą była wizytacja Komunistycznej Partii Austrii. Opublikowano wtedy wspólny komunikat, który stwierdzał, że delegacje obu partii omówiły bieżące problemy międzynarodowego ruchu komunistycznego i robotniczego.

Jak można zauważyć lata $70 \mathrm{XX}$ wieku $\mathrm{w}$ relacjach polsko-austriackich na szczeblu dyplomatycznym odznaczają się intensywnością wzajemnych wizyt, delegacji i umów.

Przedstawiciele obu państw oceniali wzajemne relacje jako bardzo dobre i na wysokim poziomie, które cechowały: intensywny dialog polityczny, wizyty państwowe, gospodarcze i żywe kontakty środowisk twórczych.

W latach 80. w stosunkach dyplomatycznych Austrii, Polsce przypadała rola szczególna. Jak zostało wcześniej wspomniane Polska była pierwszym krajem związanym z ZSRR, w którym austriacki minister spraw zagranicznych złożył oficjalną wizytę. Po intensywnej wymianie wizyt $\mathrm{w}$ latach 70. przyszedł czas kontynuację w latach 80 . w miarę istniejących możliwości polityki odprężenia w Europie i świecie i dostarczania jej nowych bodźców. W maju 1980 roku w Polsce spotkali się ministrowie spraw zagranicznych gdzie omówili całokształt stosunków polsko-austriackich i stwierdzono, że w ostatnich latach korzystnie rozwinęła się współpraca dwustronna.

Analizując artykuł dr W. Pahr'a na temat aktualnych stosunków polsko-austriackich, można stwierdzić, że wysoki poziom wzajemnych stosunków stanowi przykład pełnej zaufania współpracy między państwami o różnych systemach społecznych.

W. Pahr uważał, że model austriacko-polski stanowi istotny wkład w dzieło współpracy europejskiej na szczeblu dyplomatycznym ${ }^{27}$.

Jednym z punktów ciężkości wzajemnych stosunków była wielostronna współpraca gospodarcza.

Na zaproszenie ministra I. Tejchmy w dniach 24-28 marca 1980 roku złożył wizytę w Polsce austriacki minister Oświaty i Sztuki Fred Sinowatz.

26 Archiwum MSZ, Wizyta min. Sprawiedliwości Ch. Brody w Polsce, Z 1/84, W. III, 1978.

27 W. Pahr, Aktualny stan stosunków austriacko-polskich, w: Austria-Polska. Czasopismo Gospodarczo-Kulturalne, nr 2 (113) czerwiec 1981, s. 11. 
Rozmowy dotyczyły kształcenia politycznego w Polsce, oraz zwiedził szkoły podstawowe, zawodowe i przedszkola ${ }^{28}$. W dniach od 1 do 3 maja 1980 roku miała miejsce oficjalna wizyta w Polsce Ministra Spraw Zagranicznych Austrii Willibalda Pahra. Wizyta miała na celu wymianę poglądów w kierunku podtrzymania pozytywnych elementów w polityce zagranicznej Austrii. W trakcie tej wizyty miało miejsce podpisanie umowy między Polską, a Austrią o dostawach zboża ${ }^{29}$.

W dniach 25-26 czerwca 1980 roku przebywał w Austrii z oficjalną wizytą Członek Biura Politycznego KC PZPR, Prezes Rady Ministrów Edward Babiuch. Minister Babiuch został przyjęty przez prezydenta Austrii Kirchschlägera oraz odbył rozmowy na tematy międzynarodowe i bilateralne z Kreiskym. Podstawowym zagadnieniem spotkania były kwestie dotyczące podpisania kontraktu na wieloletnie dostawy węgla ${ }^{30}$.

W dniach 9-11 listopada 1981 roku z wizytą w Austrii przebywał minister spraw zagranicznych PRL Józef Czyrek. Wizyta przebiegała w przyjaznej atmosferze, obie strony starały się zachować dotychczasową drogę współpracy pomimo trudności na polu politycznym i gospodarczym. Obaj ministrowie wyrazili pogląd, że niezbędne są kroki ku poprawie sytuacji międzynarodowej ${ }^{31}$.

W 1983 roku w Polsce przebywała delegacja austriacka, której przewodniczył związkowy minister rolnictwa i leśnictwa Günther Haiden. Delegacja austriacka zapoznała się ze stanem oraz problemami polskiego rolnictwa i przemysłu środków spożywczych ${ }^{32}$. W 1985 roku z oficjalną wizytą do Austrii udał się wiceminister rolnictwa i gospodarki żywnościowej Kazimierz Grzesiek. Celem spotkania było pogłębienie tematów dotyczących rolnictwa i przemysłu środków spożywczych w ramach Austriacko-Polskiej Mieszanej Komisji ds. Współpracy Gospodarczej, Przemysłowej i Naukowo-Technicznej ${ }^{33}$.

W dniach 21-24 września 1987 roku przebywał w Polsce kanclerz Austrii Franz Vratnitzky. Został przyjęty przez przewodniczącego Rady Państwa PRL Wojciecha Jaruzelskiego. Franz Vratnitzky wygłosił w Sejmie

28 Archiwum MSZ, Wizyta w Polsce Ministra Oświaty i Sztuki Austrii Freda Sinowatza, sygn. Z 43/84, W. V, 1980.

${ }_{29}$ Archiwum MSZ, Wizyta w Polsce Ministra Spraw Zagranicznych W. Pahra, sygn. Z 43/84, W. V, 1980.

30 Archiwum MSZ, Wizyta premiera E. Babiucha w Austrii 25-26 VI 1980, sygn. Z 43/84, W. V, 1980.

${ }^{31}$ Wizyta polskiego ministra spraw zagranicznych Józefa Czyrka w Austrii, w: Austria-Polska. Czasopismo Gospodarczo-Kulturalne nr 5 (123) czerwiec 1982, s. 11.

${ }^{32}$ Wspótpraca austriacko-polska w dziedzinie rolnictwa i leśnictwa, w: Austria-Polska. Czasopismo Gospodarczo-Kulturalne, nr 1 (146) czerwiec 1986, s. 9.

33 Ibidem. 
odczyt, w którym przedstawił stanowisko Austrii w sprawie pokojowego współistnienia państwa o odmiennych systemach społeczno-politycznych w Europie ${ }^{34}$. W listopadzie 1988 roku złożył wizytę w Austrii premier Rakowski w towarzystwie ministra Wilczka i wiceministra Klęka. Premier wygłosił odczyt na temat oczekiwanych nowych ustaw gospodarczych ${ }^{35}$.

Warto wspomnieć, ze Austria nie dołączyła się do sankcji gospodarczych wobec Polski, zastosowanych przez większość państw zachodnich. Nie uznawała ich bowiem jako adekwatny środek okazywania zainteresowania wobec przemian w Polsce.

Proces demokratycznych i gospodarczych reform w Polsce wzbudził w Austrii sympatię i podziw. Austria była gotowa wnosić swój wkład w dzieło pomocy dla reform gospodarczych w Polsce.

\subsection{Kontakty polityczne między Polska, a Austrią}

Oprócz wyżej opisanych stosunków dyplomatycznych, niezwykle istotną rolę $\mathrm{w}$ funkcjonowaniu państwa odgrywają jego kontakty polityczne. Zgodnie $\mathrm{z}$ definicją jest to całokształt relacji zachodzących we wspólnocie politycznej, obejmują kontakty między podmiotami politycznymi. Z historycznego punktu widzenia stosunki polsko-austriackie na płaszczyźnie politycznej rozwijały się pomyślnie. Geograficzne położenie i neutralny status polityczny Austrii mianują go do roli „pomostu” między ugrupowaniami państw o odmiennych systemach politycznych.

Kontakty polityczne z Austrią były jednym z ważniejszych elementów polityki zagranicznej PRL. Warto podkreślić, że dialog między Austrią, a Polską był niezwykle ważny ponieważ były to państwa o odmiennych ustrojach społeczno-gospodarczych. W latach 70. utrzymywały się żywe kontakty między Polskim, a Austriackim MSZ.

Wiosną 1979 roku odbyły się konsultacje na szczeblu ekspertów do spraw bezpieczeństwa i współpracy w Europie ${ }^{36}$.

W 1970 roku prezes Polskiego Banku Narodowego L. Siemiątkowski udał się z wizytą do Austrii w celu odwiedzenia Austriackiego Banku Narodowego. Wizyta miała na celu pogłębienie zrozumienia różnych problemów między instytucjami o podobnych zadaniach ${ }^{37}$.

34 Austria-Polska. Czasopismo Gospodarczo-Kulturalne, nr 2 (159) czerwiec 1988, s. 20.

35 R. Sallinger, Pomyślny rozwój austriacko-polskiego handlu zagranicznego, w: Austria-Polska. Czasopismo Gospodarczo-Kulturalne, nr 2 (166) czerwiec 1989, s. 29.

36 Archiwum MSZ, Stosunki polsko-austriackie, sygn. Z43/84, W.5, t. A. 220, s. 18.

37 W. Schnitz, Kontakty między bankami emisyjnymi Polski i Austrii, w: Austria-Polska. Czasopismo Gospodarczo-Kulturalne, nr 2 (83) czerwiec 1972, s. 45. 
Rok później, dyrektor Kloss i dyrektor Rieger udali się do Warszawy gdzie prowadzili rozmowy nie tylko z kierownictwem Polskiego Banku Narodowego, ale również z wiceprezesem Rady Ministrów E. Szyrem. Tematem rozmów była organizacja i działalność Banku Narodowego, a także kształtowanie się cen w Polsce, ze szczególnym uwzględnieniem towarów handlu zagranicznego ${ }^{38}$.

W 1972 roku prezes Towarzystwa Austriacko-Polskiego Theodor Kanitzer został odznaczony Krzyżem Oficerskim Orderu Odrodzenia Polski. Order ten został nadany przez Radę Państwa PRL za zasługi w dziedzinie stosunków austriacko-polskich. Odznaczenie wręczył w Wiedniu ambasador Lesław Wojtyga ${ }^{39}$. W tym samym roku Ferdinand Neureiter oraz Rudolf Jagodtisch i Josef Hamm zostałi odznaczeni za zasługi dla kultury polskiej przez ambasadora PRL w Austrii Lesława Wojtygę. Odznaczenie zostało przyznane przez ministerstwo kultury i sztuki w Warszawie ${ }^{40}$. W lipcu 1972 roku prowadzono rokowania w sprawie zawarcia obustronnej umowy o wzajemnym zniesieniu obowiązku wizowego. W 1973 roku miała miejsce wizyta Sekretarza Generalnego Międzynarodowego Towarzystwa im. M. Lenaua prof. Nikolausa Britza w Polsce, który wygłosił referat z dziedziny metodyki nauczania języka niemieckiego oraz literatury austriackiej.

W tym samym roku przebywał w Polsce na zaproszenie Towarzystwa Polsko-Austriackiego, Theodor Kanitzer, który swoją wizytą utrzymał poprawne stosunki między Towarzystwem Austriacko-Polskim i Towarzystwem Polsko-Austriackim, a także przekazał 51 tys. szylingów na rzecz odbudowy Zamku Warszawskiego ${ }^{41}$. W czerwcu 1974 roku w Wiedniu obradowała polsko-austriacka komisja mieszana. Omówiono na niej wprowadzenie pełnej liberalizacji dla polskiego eksportu do Austrii ${ }^{42}$. W listopadzie 1974 roku przebywała w Austrii polska delegacja Ministerstwa Budownictwa i Materiałów Budowlanych pod przewodnictwem wiceminister E. Dobija. Polska delegacja zwiedziła przemysłowe i komunalne obiekty budowlane oraz zapoznała się z austriacką technologią budownictwa ${ }^{43}$. Następnie na zaproszenie austriackiej firmy C. Hartwig, odbyło się spotkanie firm Chemie Linz AG oraz firmy Adria w Polsce. Delegacja austriacka zapoznała się z możliwościami w dziedzinie przeładunku

38 Ibidem, s. 45.

39 Prezes dr Kanitzer odznaczony polskim orderem wysokiej rangi, w: Austria-Polska. Czasopismo Gospodarczo-Kulturalne, nr 2 (87) czerwiec 1973, s. 39.

${ }^{40}$ Ferdinand Neureiter, w: Austria-Polska. Czasopismo Gospodarczo-Kulturalne, nr 2 (87) czerwiec 1973, s. 46.

41 Austria-Polska. Czasopismo Gospodarczo-Kulturalne, nr 1 (90) czerwiec 1974, s. 46.

42 MSZ, Stosunki dyplomatyczne Polski 1944-1981r..., s. 20.

43 Austria-Polska. Czasopismo Gospodarczo-Kulturalne, nr 1 (94) czerwiec 1975, s. 57. 
i transportu surowców fosforowych oraz przeprowadzono szereg rozmów z przedstawicielami Gospodarki Morskiej oraz Kolei Państwowych ${ }^{44}$.Pod koniec tego samego roku na zaproszenie KC PZPR przebywała delegacja Komunistycznej Partii Austrii. Przewodniczący Franz Muhri spotkał się z I sekretarzem PZPR Edwardem Gierkiem. Obie partie porozumiały się co do aktywnej współpracy w przygotowaniu i zwołani konferencji partii komunistycznych i robotniczych Europy ${ }^{45}$. Na początku 1975 roku, na zaproszenie Prezesa Rady Ministrów Piotra Jaroszewicza, przebywał z nieoficjalna wizytą kanclerz Republiki Austrii Bruno Kreisky. Szefowie obu rządów omówili perspektywy dalszego rozwoju stosunków dwustronnych $^{46}$. Natomiast pod koniec roku z nieoficjalną wizytą przebywał w Austrii Piotr Jaroszewicz. Była to kontynuacja obustronnego dialogu.

W dniach 17-20 listopada 1976 roku gościła w Austrii delegacja dyrekcji naczelnej zjednoczenia przemysłu rafineryjnego i petrochemicznego, która odbyła rozmowy z ÖMV w sprawie budowy w Polsce instalacji do produkcji koksu naftowego ${ }^{47}$.

W styczniu 1978 roku miały miejsce w Warszawie rozmowy gospodarcze między Europejskim Instytutem Naddunajskim, a Polską Izbą Handlu Zagranicznego. Celem spotkanie były rozmowy dotyczące kwestii eksportu i importu. Obie strony podkreśliły jak wielką wagę przywiązują do poszerzania współpracy gospodarczej między państwami ${ }^{48}$.

20 listopada 1979 roku miała miejsc wizyta Theodora Kanitzera, dra Kepnika oraz Lcana Stooda z Zarządu Towarzystwa Austriacko-Polskiego w Polsce u Prezesa Polskiej Izby Handlu Zagranicznego. Prezes Janusz Burakiewicz został zaproszony przez Kanitzera do Austrii w celu wygłoszenia referatu w trakcie Forum Gospodarczego Towarzystwa Austriacko-Polskiego ${ }^{49}$.

Pod koniec lat 70 nastąpiło osłabienie kontaktów politycznych. Polegało to na zmniejszonej liczbie zaproszeń ze strony austriackiej oraz przekładaniu przez nią na później już ustalonych wizyt ${ }^{50}$. Spadek aktywności politycznej mógł być spowodowany znacznym zaangażowaniem się strony austriackiej we własne problemy wewnątrzpolityczne. Szczególne miejsce $\mathrm{w}$ kontaktach politycznych między obu państwami zajmowała współpraca z Komunistyczną Partią Austrii. Według informacji zawartych

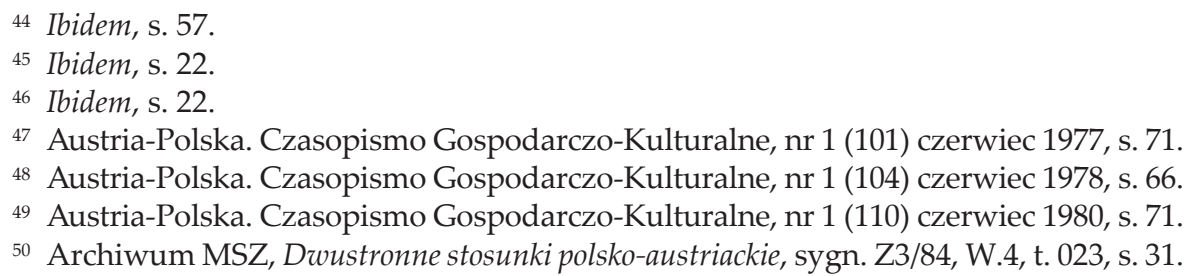


w sprawozdaniu z Archiwum MSZ wynika, że komuniści austriaccy wnosili wkład w rozwój autentycznej współpracy polsko-austriackiej ${ }^{51}$.

W początku lat 80 istotnym cele polityki zagranicznej PRL było zmniejszenie wyraźnych dysproporcji pomiędzy Polską a Austrią. Wydarzenia z grudnia 1981 roku nie przerwały polsko-austriackich kontaktów politycznych i w nieznacznym stopniu zmieniły sposób podejścia Austrii do kontynuowania dialogu politycznego z Polską. Znalazło to swój wyraz w wizytach ministra J. Czyrka w Austrii w maju 1981 roku, a także w okazjonalnych spotkaniach szefów dyplomacji polskiej i austriackiej w ONZ ${ }^{52}$. Po roku 1982 stosunki polsko-austriackie osłabiły się. Równocześnie poszerzyła się współpraca na płaszczyźnie społecznej. W 1983 roku na zaproszenie Forum Gospodarczego Towarzystwa Austriacko-Polskiego, przebywał w Austrii dyrektor naczelny Międzynarodowych Targów Poznańskich Andrzej Byrt ${ }^{53}$.

W okresie kryzysu politycznego Austria odegrała pozytywną rolę wytyczając drogę do normalizacji stosunków z Polską przez inne państwa zachodnie. Pierwszym przedstawicielem państw demokratycznych, który odwiedził Polskę po 1981 roku był minister spraw zagranicznych Austrii Leopold Gratz w 1984 roku $^{54}$. W 1984 roku miały miejsce rozmowy o stosunkach gospodarczych między Polską, a Austrią organizowane przez Forum Gospodarcze Towarzystwa Austriacko-Polskiego między przedstawicielami handlowymi Polski i Austrii w Wiedniu ${ }^{55}$. Natomiast 24 stycznia 1986 roku Ambasador PRL Marian Krzak gościł delegację Zarządu Towarzystwa Austriacko-Polskiego w Polsce. Ambasador Marian Krzak wyraził słowa uznania dla Towarzystwa Austriacko-Polskiego za wielostronną działalność między obu krajami ${ }^{56}$. Jednym z ważniejszych wydarzeń schyłku lat 80 była wizyta kanclerza Klausa Vraniztkiego w 1987 roku $^{57}$. Władze komunistyczne Polski podpisały jeszcze cztery umowy pochodzące z lat 1987-1989.

W 1988 roku Rada Państwa PRL odznaczyła Krzyżem Zasługi Polskiej Rzeczypospolitej Ludowej wojewodę federalnego kraju Dolnej Austrii. Uroczystość ta odbyła się w ambasadzie Polski w Wiedniu, a odznacze-

51 Ibidem, s. 33.

52 Archiwum Akt Nowych, Notatka o ważniejszych aspektach stosunków polsko-austriackich, sygn. KC PZPR LXXVI-607, 6/9/82/WZ, s. 2-3.

53 Austria-Polska. Czasopismo Gospodarczo-Kulturalne, nr 2 (130) czerwiec 1983, s. 37.

54 A. Kisztelińska, Traktaty polsko-austriackie..., s. 24.

55 Austria-Polska. Czasopismo Gospodarczo-Kulturalne, nr 1 (140) czerwiec 1985, s. 31.

56 Austria-Polska. Czasopismo Gospodarczo-Kulturalne, nr 1 (146) czerwiec 1986, s. 32.

57 Austria-Polska. Czasopismo Gospodarczo-Kulturalne, nr 2 (159) czerwiec 1988, s. 20. 
nia wręczył ambasador Polski Marian Krzak ${ }^{58}$. W 1989 roku miała miejsce wizyta delegacji Zjednoczonego Stronnictwa Ludowego pod przewodnictwem Tadeusza Szelachowskiego, która miała dwa aspekty: rolniczy i partyjny. Zapoznano się z funkcjonowaniem gospodarstw rolnych w Austrii oraz pracami instytucji i zakładów działających na rzecz rolnictwa. Oddzielny aspekt wizyty stanowiły kontakty partyjne na płaszczyźnie ZSL i Austriackiej Partii Ludowej ${ }^{59}$.

Dwadzieścia lat współpracy pomiędzy Polską a Austrią w latach 1970-1989 przedstawia nam bardzo ciekawą charakterystykę opisywanego tematu. Wnioski, jakie się nasuwają same, to te, iż dwa państwa o przeciwstawnych biegunach politycznych, wbrew utartym schematom i zależnością, potrafiły ułożyć między sobą bardzo poprawne stosunki polityczne.

Po doświadczeniach piętnastu lat rządów Gomułki i fiaska reform zapowiadanych w 1956 roku kredyt zaufania, jakim społeczeństwo obdarzyło nową ekipę, był znacznie mniejszy. Dla uspokojenia nastrojów społecznych i zyskania akceptacji dla nowej ekipy Gierek starał się z jednej strony zwiększyć pozory demokracji (polityka odprężeniowa), a z drugiej dokonać takiej reformy gospodarki, aby równocześnie poprawić stopę życiową ludności, jak i zwiększyć produkcję przemysłową. Tym samym rozpoczęła się faza polityki pokonsumpcyjnej. Uznano, że tego rodzaju polityka może być sfinansowana ze środków zewnętrznych - kredyty zagraniczne i import technologii.

Lata siedemdziesiąte to okres bujnego i euforycznego rozwoju współpracy gospodarczej, natomiast lata osiemdziesiąte to okres stanu wojennego, który niewątpliwie wpłynął na zmniejszenie wymiany gospodarczej. Niestety, lata osiemdziesiąte charakteryzują się załamaniem stosunków gospodarczych miedzy tymi dwoma państwami. Główną przyczyną było wprowadzenie stanu wojennego w Polsce. Mimo tak dramatycznej sytuacji, w jakiej znalazło się polskie społeczeństwo, wymiana między tymi państwami istniała nadal. Zmienił się nieco charakter tej wymiany z czynnika oficjalnego państwowego na czynnik bardziej osobisty - ludzki. Było to związane z represjami władz PRL w stosunku do szeroko rozumianej opozycji.

58 Ibidem, s. 20.

59 Archiwum MSZ, Notatka nt. wizyty w Austrii delegacji Zjednoczonego Stronnictwa Ludowego 29.01-3.02. $1989 r$. 


\section{Zusammenfassung}

\section{POLNISCH-ÖSTERREICHISCHEN DIPLOMATISCHEN BEZIEHUNGEN UND POLITISCHE KONTAKTE ZWISCHEN 1970 UND 1989}

Österreichisch-polnischen Beziehungen in der modernen Geschichte sind sehr interessante und spannende Thema für den modernen Forscher. Zwanzig Jahre der Zusammenarbeit zwischen Polen und Österreich in die späten 1970er Jahre-1989 gibt uns eine sehr interessante Eigenschaften dieses Themas. Zwei Staaten der gegnerischen politischen Pole, im Gegensatz zu der breit-Systeme, Abhängigkeit und konnten nur sehr richtige politische Beziehungen untereinander anordnen. Beziehungen zwischen Polen und Österreich in den späten Hauptrollen und achtziger haben eine andere Dimension als unter Habsburg Souveränität. Sie waren vor allem die Beziehung zwischen zwei souveränen Staaten. Im Interesse der polnischen und Österreich belagern der Versailler Frieden regieren, weil verhängnisvollen Ende des internationalen Gegebenheiten zusammen mit seinen Zusammenbruch bedroht. Sozio-ökonomische Entwicklung von Österreich, die nach Lösung des sogenannten österreichischen Problems stattgefunden hat, steckte es in eine Reihe von schnell wachsenden, Schaffung günstiger Voraussetzungen für friedliche Zusammenarbeit, die Stärkung der Polnisch-österreichischen politischen Kontakte, diplomatische, kulturelle, akademische und gegenseitig vorteilhaften Zusammenarbeit wirtschaftlich. Das Ziel dieser Arbeit ist, die Zusammenarbeit zwischen Polen und Österreich von 1970 bis $1989 \mathrm{zu}$ analysieren. Sie werden einen Überblick über die historische Polnisch-österreichischen-Kontakte durch eine kurze Chronologie der Hervorhebung des historischen und politischen Zugangs zur Stärkung der Polnisch-österreichischen Zusammenarbeit vorgestellt. Diplomatische Beziehungen werden als politische Kontakte und bilden eine "Brücke" zwischen Ländern mit verschiedenen politischen Systemen charakterisiert das einen wichtigen Bestandteil der Außenpolitik, der Volksrepublik Polen bildete. 